McConkey, B., Fraser, G. M., and Bligh, A. S. (1965). Annals of the Rheumatic Diseases, 24, 219.

Masi, A. T. (1965). Fournal of Chronic Diseases, 18, 35.

Masi, A. T., Hartmann, W. H., and Shulman, L. E. (1965). fournal of Chronic Diseases, 18, 1

Modell, W. (1967). Science, 156, 346.

Monro, A., Secundus (1785). A Description of all the "Bursae Mucosae" of the Human Body. Edinburgh, Elliott.

Monro, A., Secundus (1799). Abbildungen und Beschreigungen der Schleimsäcke des menschlichen Körpers, ed. J. C. Rosenmüller, Leipzig, Breitkopf and Haertel.

Movitt, E. R., and Davis, A. E. (1953). American fournal of the Medical Sciences, 226, 516 .

Mowat, A. G. (1969). British Medical fournal, 3, 717

Mowat, A. G., Hothersall, T. E., and Aitchison, W. R. C. (1969). Annals of the Rheumatic Diseases, 28. 303.

Mulhern, L. M., Masi, A. T., and Shulman, L. E. (1966). Lancet, 2, 508.

Nettelbladt, E. (1960). Acta Rheumatologica Scandinavica, 6, 256

Park, D. C., and Swinburne, K. (1964). British Medical łournal, 1, 86.
Partridge, R. E. H., and Duthie, J. J. R. (1963). British Medical fournal, $1,89$.

Rajmann, E. (1966). Zeitschrift für Rheumaforschung, 25, 350.

Reah, T. G. (1963). Proceedings of the Royal Society of Medicine, $\overline{\mathbf{5 6}}$

Rimoin, D. L., and Wennberg, J. E. (1966). Journal of the American Medical Association, 196, 617.

Roy, L. M. H., Alexander, W. R. M., and Duthie, J. J. R. (1955). Annals of the Rheumatic Diseases, 14, 63.

Scott, W. A. M. (1969). Practitioner, 202, 802.

Short, C. L., Bauer, W., and Reynolds, W. E. (1957). Rheumatoid Arthritis, p. 323. Cambridge, Massachusetts, Harvard University Press.

Tait, G. B. W., Bach, F., and Dixon, A. St. J. (1965). Annals of the Rheumatic Diseases, 24, 273.

Whittingham, S., Balazs, N. D. H., and Mackay, I. R. (1967). Medical fournal of Australia, 2, 639 .

Wilkinson, P., Jeremy, R., Brooks, F. P., and Hollander, J. L. (1965). Annals of Internal Medicine, 63, 109.

\title{
Autoimmunization with Irradiated Tumour Cells in Human Malignant Melanoma
}

\author{
R. L. IKONOPISOV,* M.D. ; M. G. LEWIS, † M.D., M.R.C.PATH. ; I. D. HUNTER-CRAIG, $\ddagger$ M.A., M.CHIR., F.R.C.s. \\ D. C. BODENHAM, $§$ F.R.C.S., F.R.C.s.ED. ; T. M. PHILLIPS, || F.R.M.S. ; C. I. COOLING, I F.R.C.S. \\ J. PROCTOR,** M.B., B.s. ; G. HAMILTON FAIRLEY,†† M.A., D.M., F.R.C.P. ; P. ALEXANDER, $\ddagger$ PH.D., D.sC.
}

British Medical fournal, 1970, 2, 752-754

\begin{abstract}
Cummary: Thirteen patients have been immunized with $\checkmark$ their own irradiated melanoma cells on one or more occasions. Following these autografts tumour-specific cytotoxic antibodies were produced, the longest response lasting 14 days. This procedure had no apparent effect on the course of the disease in these patients.
\end{abstract}

\section{Introduction}

Antibodies cytotoxic to the patient's own malignant melanoma cells are present in most patients who have localized disease but absent in those with widely disseminated tumour (Lewis, 1967; Lewis et al., 1969). We have previously shown in individual patients that as the disease progresses the antibodies disappear from the blood (Lewis et al., 1969). For this reason we decided to immunize patients, who did not have antibodies, with their own irradiated malignant cells to determine whether they were capable of forming antibodies if challenged in this way.

\section{Patients and Methods}

Clinical Assessment of Patients.-For the purposes of this study the patients were classified in three grades: Grade 1, Malignant melanoma confined to the primary anatomical site; Grade 2, Invasion of regional lymph nodes with or without local satellite nodules; and Grade 3, Tumour spread beyond

* Head, Dermatology Department, Oncological Research Institute, Sofia, Bulgaria. In receipt of U.I.C.C. E.R.I.C. Fellowship of American Cancer Society and Wellcome Foundation Grant (U.K.) at Chester Beatty Research Institute, Belmont, Sutton, Surrey.

t Consultant Pathologist, Westminster Hospital, London S.W.1.

‡ Senior Surgical Registrar, Westminster Hospital, London S.W.1. Now Consultant Surgeon, Redhill Group of Hospitals, Surrey.

(f Consultant Surgeon, Frenchay Hospital, Bristol.

Technical Officer, Chester Beatty Research Institute, Belmont, Sutton, Surrey.

I Consultant Surgeon Royal Marsden Hospital, London S.W.3. Gr 'don Jacob's Fellow, Chester Beatty Research Institute, Belmont, Sutton, Surrey.

tt Consultant Physician, Chester Beatty Research Institute, Royal Marsden Hospital, London S.W.3, and St. Bartholomew's Hospital, London E.C.1.

‡ђ Professor of Radiobiology, Chester Beatty Research Institute, Belmont, Sutton, Surrey. the regional lymph nodes. Three patients with Grade 2 and 10 with Grade 3 disease were given one or more autografts of their own irradiated tumour cells.

Preparation of Autografts.-The tumour was received fresh from operation and minced with scissors and scalpel to obtain a cell suspension in tissue culture medium 199. No enzymes were added. Between 60 and $500 \times 10^{6}$ cells in $6 \mathrm{ml}$. of TC 199 were irradiated in a glass Petri dish with 12,000 rads. The cell suspension was then transferred to a sterile syringe, and $1-\mathrm{ml}$. portions were injected subcutaneously at six sites-the outer aspects of both arms, each side of the anterior abdominal wall, and the outer aspect of both thighs. This was preceded in every case by an intradermal test dose of $0.1 \mathrm{ml}$. of cell suspension, any local skin reaction being noted. The remainder of the cell suspension was concentrated in a mixture of TC $199,20 \%$ fetal bovine serum, and $10 \%$ dimethylsulphoxide, and cooled at $1^{\circ}$ per minute to $-20^{\circ} \mathrm{C}$ before being placed in liquid nitrogen. Informed consent for these procedures was obtained in each case.

Tests for Detecting Autoantibodies.-Three separate techniques were used to detect the presence of autoantibodies: (1) the complement-dependent cytotoxicity test using a method modified from Pulvertaft; (2) the complement-dependent inhibition of R.N.A. synthesis; and (3) indirect membrane immunofluorescence. These three techniques have already been described in detail (Lewis et al., 1969), the only modification being that, on thawing, the cells stored in liquid nitrogen were washed very thoroughly in TC 199 before being tested for membrane immunofluorescence, as dimethylsulphoxide interferes with this reaction. When titrations of the sera were undertaken, an end-point of $>1: 16$ was regarded as being significant. The end-point was taken at the last dilution to show $25 \%$ of cells with positive speckled membrane reactions.

\section{Results}

A total of 18 patients were given autografts, but in five of these the detection of antibodies proved impossible owing to the poor viability of the frozen melanoma cells when they were thawed. In the remainder satisfactory preparations were obtained, and a total of 25 autografts were given to 13 patients. The results are summarized in Table $I$. 
TABLE I

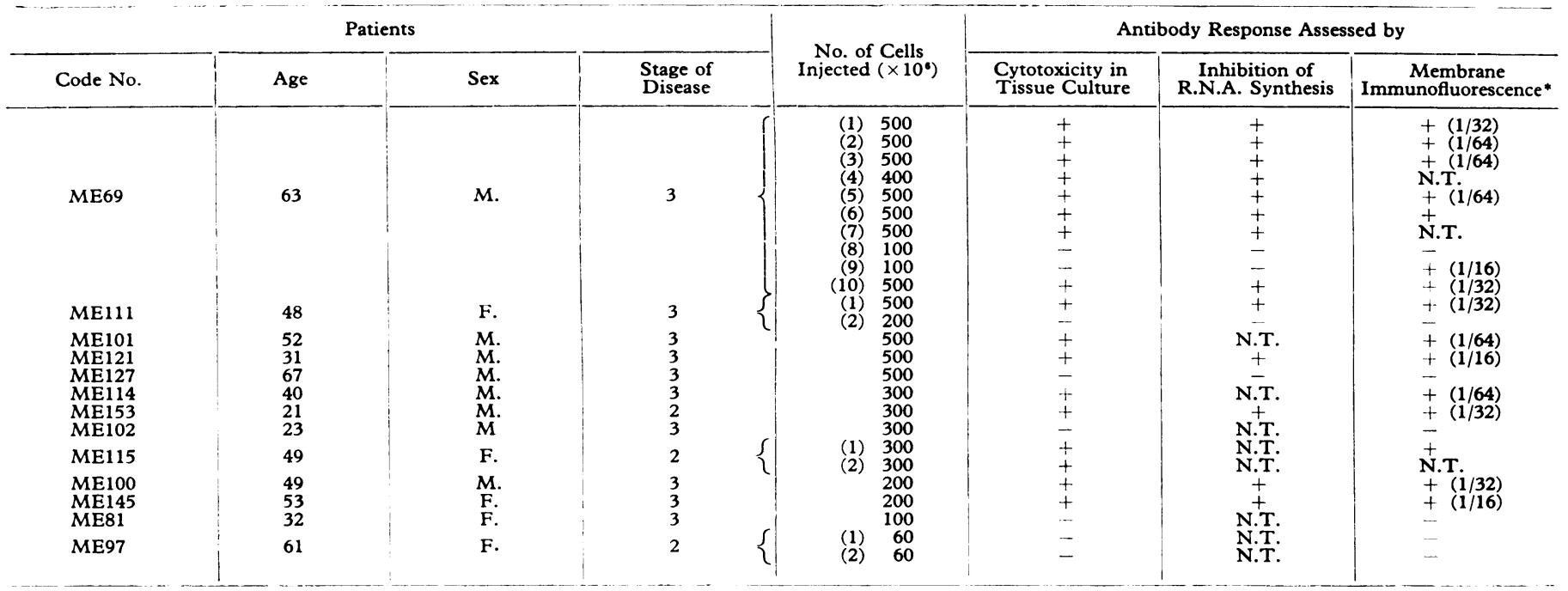

N.T. $=$ Not tested. $\quad$ *Value in parentheses shows highest dilution at which serum is positive.

Two factors influenced the response to autoimmunization. Firstly, the formation of antibodies was related to the number of cells used in the autograft. Immunization with $100 \times 10^{6}$ cells or less failed to provoke antibody formation, whereas $500 \times 10^{6}$ almost invariably did so (Table II). This is well illustrated by the results in Patient ME69, who received 10 autografts over a period of six months. Whenever he was given $500 \times 10^{6}$ cells antibodies appeared in the blood, but he failed to respond to $100 \times 10^{6}$ cells. This was not due to an inability to form antibodies, as he did so on his final immunization with $500 \times 10^{6}$ cells given after treatments with $100 \times 10^{6}$ cells (Table I; Fig. 1).

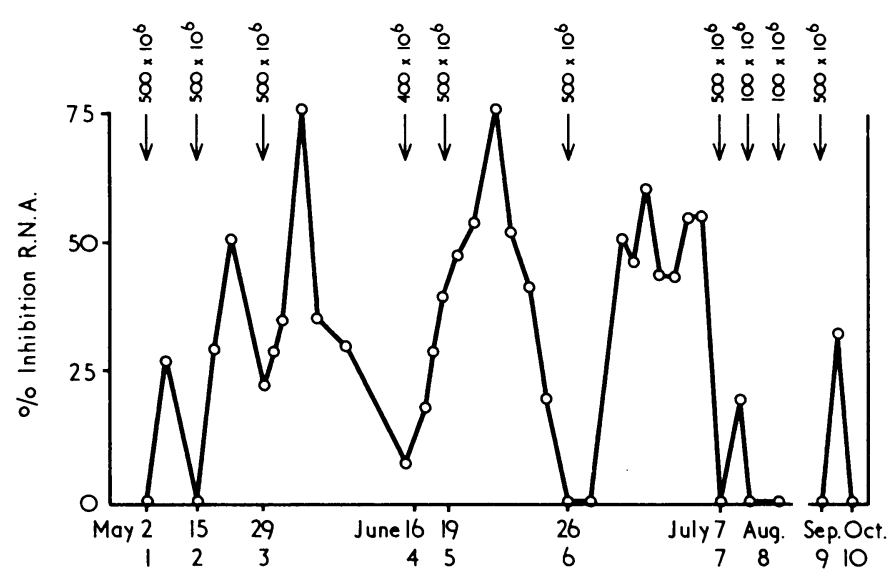

FIG. 1.-Percentage inhibition in R.N.A. synthesis by the addition of following immunization with autologous irradiated tumour cells on 10 separate occasions in different doses. (Patient ME69.) the patient's serum plus human complement to his own melanoma cells

Secondly, the duration of the response, which was always transitory, tended to be longer in patients with little residual disease. This is illustrated by the results in Patient ME115. $\dot{H}$ e had grade 2 disease, which was all removed macroscopically; after immunization with $300 \times 10^{1}$ irradiated autologous melanoma cells antibodies were produced which were still present at the 10th day, but had disappeared by the 14th day (Fig. 2). In some patients with very advanced disease the response was over by the sixth day. Inducing a transient appearance of cytotoxic antibodies by injecting patients with their own irradiated melanoma cells had no detectable effect, either beneficial or harmful, on the course of the disease.

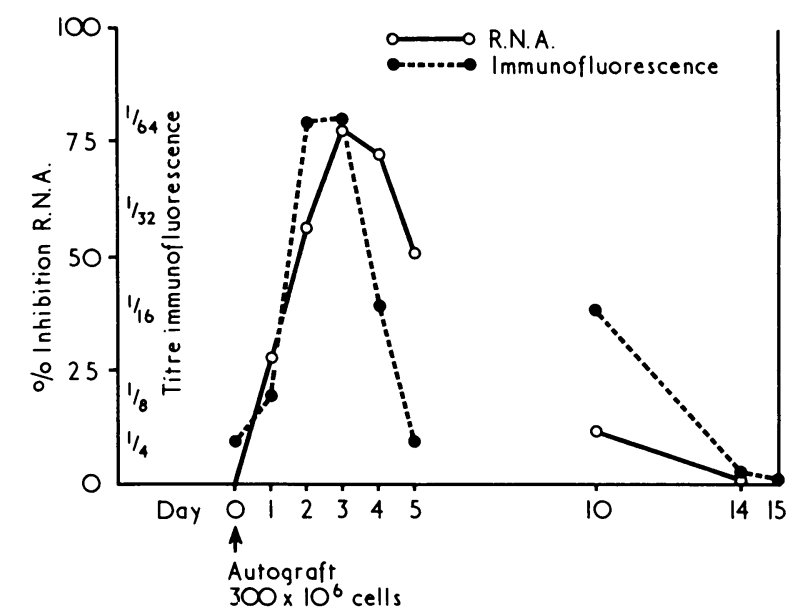

FIG. 2.-Percentage inhibition in R.N.A. synthesis and the titre of membrane immunofluorescence by the addition of the patient's serum plus human complement to his own melanoma cells following an autograft of $300 \times 10^{6}$ irradiated melanoma cells. (Patient ME115.)

TABLE II

\begin{tabular}{c|c|c|c}
$\begin{array}{c}\text { No. of Cells } \\
\text { Injected as } \\
\text { Irradiated }\end{array}$ & $\begin{array}{c}\text { No. of } \\
\text { Autografts }\end{array}$ & $\begin{array}{c}\text { No. Forming } \\
\text { Cytotoxic } \\
\text { Antibodies }\end{array}$ & $\begin{array}{c}\text { No. Failing to } \\
\text { form Cytotoxic } \\
\text { Antibodies }\end{array}$ \\
\hline Autografts $\left(\times 10^{\circ}\right)$ & 2 & 0 & 2 \\
\hline 60 & 3 & 0 & 3 \\
100 & 4 & 3 & 1 \\
200 & 4 & 3 & 0 \\
300 & 11 & 1 & 1 \\
\hline 500 & 25 & 17 & 8 \\
\hline Total & 11 & & \\
\hline
\end{tabular}

The results reported here, together with our previous observations (Lewis et al., 1969), suggest the following pattern of the immunology of malignant melanoma. Patients with localized disease usually have tumour-specific cytotoxic antibodies, reacting only against their own melanoma cells. These are lost once the disease becomes generalized with distant metastases, but most patients are capable of forming them again if immunized at multiple sites with a large number of their own irradiated malignant cells. This raises 
the vital question of the role of such antibodies in this malignant disease.

We have no clinical evidence that antibodies have any effect on the tumour when it is growing as a solid tumour. This is probably to be expected, as the concentration of antibody within a tumour may well be low and the conditions not favourable for any cytotoxic action to occur. Their presence, however, may prevent blood-borne metastases from forming. Possibly as long as cytotoxic antibodies are present in the serum malignant melanoma cells released into the blood are killed, but once these antibodies have disappeared malignant cells are no longer killed in the blood, and distant metastases form. Such a theory is highly speculative, but it fits with the clinical fact that this tumour may metastasize to the local lymph nodes, where it remains for variable periods of time before spreading via the blood stream. It also could explain why the disease disseminates by local lymphatic routes at a time when antibodies are present, but by the blood only when antibodies are absent. A similar situation has been encountered (Alexander and Hall, 1970) in rats with primary chemically-induced fibrosarcomata, which do not give rise to blood-borne metastases until antibody has been removed.
Clearly, more work is required to clarify the role of tumour-specific antibodies in human malignant melanoma; the reason remains to be establish 2 d why circulating antibodies disappear, and the possibility that the nodes draining the tumour become incapable of responding must be considered. Our work shows that this failure to respond is not systemic as it can be reversed by autografting.

This investigation has been supported by grants made to the Chester Beatty Research Institute by the British Empire Cancer Campaign and the Medical Research Council and a special grant by the Wellcome Foundation. The co-operation of many colleagues and centres rendered the work possible-in particular $\mathrm{Mr}$. W. P. Greening, Mr. J. D. Griffiths, Mr. J. A. McKinna, of the Royal Marsden Hospital, and Mr. G. Westbury, Professor Harold Ellis, Mr. E. S. Lee, and Mr. John Blake, of the Westminster Hospital. We also thank Miss L. E. Wheeler, Mrs. G. Bhatia, Mrs. L. Baker, Mrs. F. Torlot, and Mrs. S. F. B. Bell for technical assistance.

REFERENCES

Alexander, P., and Hall, J. G. (1970). Advances in Cancer Research. In press.

Lewis, M. G. (1967) Lancet, 2, 921

Lewis, M. G., et al., (1969). British Medical fournal, 3, 547.

\title{
Clinical Significance of Dysuria in Women
}

\author{
W. E. WATERS, ${ }^{*}$ M.B., B.S., D.I.H. ; P. C. ELWOOD, ${ }^{*}$ M.D., D.P.H., D.C.H. \\ A. W. ASSCHER, $\dagger$ M.D., B.SC., M.R.C.P. ; MARGARET ABERNETHY
}

British Medical fournal, 1970, 2, 754-757

\begin{abstract}
Cummary: During a community survey $22 \%$ of women were found to have had dysuria in the previous year and half had had dysuria at some time in their lives. Various measurements were made in a random sample of 282 of these women. The means and the variances of the systolic and diastolic blood pressures in women with a past history of dysuria tended to be higher than in women who gave no such history. There were no significant differences in the means of plasma urea, plasma creatinine, and renal concentrating power between women with and without a previous history of dysuria, but a significant impairment of renal concentrating power was found in an additional group of 30 women who dated the onset of their dysuria to childhood.

These findings suggest that urinary tract infection in adult women does not usually lead to progressive impairment of kidney function, whereas infection in childhood is more often associated with kidney damage.
\end{abstract}

\section{Introduction}

Dysuria is a common symptom among women. A community survey showed that $22 \%$ of women aged 20 to 64 years had experienced dysuria in the year immediately preceding the survey and that $48 \%$ had had dysuria at some time in their lives (Waters, 1969). General practice studies suggest that more than half of all women presenting with dysuria are

* Member of Scientific Staff, M.R.C. Epidemiology Unit (South Wales),

Cardiff.
+ Senior Lecturer in Medicine, Welsh National School of Medicine,
Cardiff.

Cardiff.
₹ Junior Technical Officer, M.R.C. Epidemiology Unit (South Wales), Cardiff. found to have bacteriological evidence of infection (Gallagher et al., 1965; Mond et al., 1965; Steensberg et al., 1969), and since nearly $30 \%$ initially without infection developed bacteriuria within three months (Gallagher et al., 1965), a comparison of kidney function among women with and without a history of dysuria may throw light on the long-term natural history of urinary tract infections. In particular it could indicate whether or not bacteriuria leads to impairment of kidney function. In this paper, therefore, the results of tests of kidney function and blood pressure measurements in women with and without a history of dysuria are compared. As dysuria in the distant past is often forgotten (Waters, 1969) it was considered desirable to pay particular attention to subjects with a history of dysuria in the year preceding the survey, when memory is likely to be more accurate. In fact there is evidence that a high proportion of these women are particularly liable to urinary tract symptoms. Since there is evidence (Smellie and Normand, 1968) that urinary tract infection in childhood is particularly apt to produce kidney damage blood pressure and renal function studies have also been performed in a group of women who dated the onset of their dysuria to childhood.

\section{Methods}

The subjects who participated in this study were drawn randomly from 2,933 women aged 20 to 64 years who answered questions about symptoms referable to the urinary tract (Waters, 1969) and who represented over $86 \%$ of the population living in a defined area of a South Wales valley. The random sample consisted of 282 women, of whom 137 $(48 \%)$ gave a history of dysuria at some time in their lives 